\title{
Detection, purification and characterization of a bacteriocin produced by Bacillus subtilis NK16 exhibits a significant antimicrobial activity against clinical Staphylococcus spp.
}

\author{
Fouad Najm Abd Khalid Jaber Kadhum Luti
}

Department of Biotechnology, College of Science, University of Baghdad, Baghdad, Iraq.

E-mail: Khalidjaber@scbaghdad.edu.iq

Received 27/3 /2016

Accepted 23/1/2017

(c) (1)

This work is licensed under a Creative Commons Attribution 4.0 International License.

\begin{abstract}
:
Bacteriocin is an important antimicrobial peptide that can be used in industrial and medical fields due to its characteristics of antibacterial, food preservation and anticancer activities. Fifty isolates of Bacillus sp were collected from different soil samples which were already recognized via morphological and biochemical identification process. The isolates were screened for bacteriocin production effective against Staphylococcus spp in order to select the highest producing isolate. The isolate NK16 showed the maximum bacteriocin production $(80 \mathrm{AU} / \mathrm{ml})$ which was further characterized as Bacillus subtilis NK 16 through using API identification system (API $20 \mathrm{E}$ and API 50CHB). Then, next step was to detect the optimal conditions for maximum bacteriocin production which were found to be brain-heart infusion broth as the best production medium with $\mathrm{pH} 6,30^{\circ} \mathrm{Cand} 2 \%$ inoculum size. Bacteriocin was partially purified by precipitation with ammonium sulphate and then separation with sephadex G-150 gel filtration. The specific activity of the resulted partial purified bacteriocin was increased to $853.33 \mathrm{AU} / \mathrm{mg}$ with 38 fold purification and $24 \%$ yield. The study of bacteriocin characterization revealed that the activity of bacteriocin was stable after $10 \mathrm{~min}$ at $20,30,40^{\circ} \mathrm{C}$ whereas $50 \%$ of the bacteriocin activity was lost after exposure to $50^{\circ} \mathrm{C}$ and decreased to approximately $20 \mathrm{AU} / \mathrm{ml}$ at 60,70 and $80 \mathrm{C}^{\circ}$. In addition, bacteriocin activity showed stability at $\mathrm{pH} 6$ and 7 for 30 min while it was decreased by approximately $50 \%$ at $\mathrm{pH} 5$ and 8 , and completely inhibited at $\mathrm{pH} 4$ and 9. On the other hand, the investigation of mode of action showed that bacteriocin has a bactericidal activity. Antimicrobial activity tests of the partial purified bacteriocin displayed a significant activity against most clinical Staphylococcus aureus and Staphylococcus epidermidis isolates, whereas it was less effective against Staphylococcus saprophyticus isolates.
\end{abstract}

Key words: Bacillus subtilis, bacteriocin, purification, characterization, antimicrobial activity and Staphylococcus spp

\section{Introduction:}

From the mid-1940s until relatively recent years, we have been

fortunate to be living through what has been termed "the Golden Age of 
Antibiotics". During this period, all of the major infections caused by bacteria and fungi have been defeated by the use of antibiotics. This period has also seen dramatic improvements in surgical procedures which have revolutionized medicine and saved countless lives [1].Unfortunately this golden age is now at the end due to the development of antibiotic resistance amongst pathogens. Such resistance was noticed immediately after the introduction of penicillin and has grown worse over the last half of this century. The development of antibiotic resistance is particularly problematic in the case of MRSA (Methicillin Resistant S. aureus), which is endemic in most hospitals worldwide [2].

Since $S$. aureus was discovered in the 1880 s, it has been considered as a potential pathogenic Gram-positive bacterium, causing serious infections, such as postoperative wound and minor skin infections. Nowadays, it is regarded as the second most common etiologic agent in blood stream and lower respiratory tract infections. Penicillinresistant $S$. aureus started to appear in hospitals only two years after the introduction of penicillin in the medical use. Within a few years later, the appearance of penicillin-resistant strains of $S$. aureus in the general community was reported [3and4].In Iraq, a considerable amount of literature has been published on penicillin-resistant strains of $S$. aureus, In this context, Kareem [5] reported that out of 74 isolates were collected from Medical City in Baghdad, 61 isolates were MRSA. In addition, Al-Dahbi [6] showed that 106 isolates of $S$. aureus were collected from 250 nasal swabs of health care workers and patients from Al- Kadhamia Teaching Hospital and Al- Numan Hospital in Baghdad that were found completely resistant to Penicillin G (100\%) and highly resistant to Cefoxitin (alternative to Methicillin)
$(94.3 \%) . H o w e v e r$, the reality is that antibiotic resistance will continue to remain a major problem in future medicine. The obvious way for this problem is to develop new antibiotics which pathogens have not previously distinguished and therefore have not developed resistance [7]. Bacteriocin could be the prospective antibiotics for $S$. aureus after the significant activity displayed by this compound against this pathogen [7]. Bacteriocins or antimicrobial peptides represent one of the best-studied microbial defense systems that serve as a good example for explaining evolution and ecological behavior of microorganisms. Furthermore, potential bacteriocins can serve as a natural alternative product to therapeutic antibiotics for treating bacterial infections as well as natural antimicrobials for food preservation [8]. Bacteriocins properties make them typical alternatives to antibiotics and they can inhibit the growth of bacteria of the same species (narrow spectrum) or other genera (broad spectrum) and their range of activity often depends on the mechanisms of action of each bacteriocin $[9,10]$. They are usually heat-stable, small peptides made of short chains of about 20-60 amino acid residues; however, longer chains can also be found [10]. Most bacteriocins are products of Gram-positive bacteria, as reported in BACTIBASE dataset. Some bacteriocins from Gram-negative bacteria have been described and are even fewer from Archaea domain [11]. In this work, we have screened a number of Bacillus isolates collected from soil for the production of bacteriocin against clinical isolates of Staphylococcus spp. The production, purification, properties and evaluation of in vitro antimicrobial activity of the bacteriocin produced were reported. 


\section{Materials and Methods:}

\section{Microorganisms}

Aerobic, spore forming Bacillus spp. were selectively isolated from different soil sources collected from Baghdad University on nutrient agar plates based on the method previously described by Nicholson and Setlow [12]. Colonies were then subjected to the identification process based on Bergey's classification of determinative bacteriology that involved morphological characteristics and regular biochemical test in order to characterize the genus [13]. After screening experiments, the higher bacteriocin producer isolate was further characterized by API system (API 50CHB, API 20E) for the identification of Gram-positive and endosporeforming bacteria according to online API database (bio Mérieux, Inc).

The selected bacterial isolates of Bacillus sp were stored at $-20^{\circ} \mathrm{C}$ in Brain Heart Infusion (BHI) broth, containing $20 \%(\mathrm{v} / \mathrm{v})$ glycerol.

$S$. aureus isolate which was used as an indicator strain in this study was provided by the Department of Biotechnology/ College of Science at University of Baghdad.

Screening of Bacillus isolates for bacteriocin production

Bacillus isolates were screened for the production of bacteriocin against $S$. aureus in liquid culture in order to select the higher bacteriocin producing isolate as follows: Erlenmeyer flasks $(100 \mathrm{ml})$ each contained $50 \mathrm{ml}$ of sterile BHI broth medium were inoculated with $1 \mathrm{ml}$ (2\% inocula) inoculum of each Bacillus isolate contained approximately $1 \times 10^{8}$ cells $/ \mathrm{ml}$. Then flasks were incubated in an orbital shaker at $30^{\circ} \mathrm{C}$ and $150 \mathrm{rpm}$ for $48 \mathrm{hrs}$. After the incubation, samples were taken for the analyses of bacteriocin [14].

Preparation of bacterial inoculums Inoculums of B. subtilis NK16 was prepared as follows: a few loopfuls growth from an overnight culture on nutrient agar was inoculated into a 100 $\mathrm{ml}$ Erlenmeyer flask containing $20 \mathrm{ml}$ of BHI broth. This culture was incubated for $24 \mathrm{hrs}$ in an incubator at $37^{\circ} \mathrm{C}$. After the incubation, a haemocytomtere was used to adjust the number of cells to be approximately $1 \times 10^{8}$ cells $/ \mathrm{ml}$ for $B$. subtilis NK16.

\section{Cultivation methods and media}

BHI broth was used for the cultivation of B. subtilis NK16 inoculated at a level of $2 \%(\mathrm{v} / \mathrm{v})$ and then incubated in an orbital shaker at $30^{\circ} \mathrm{C}$ and $150 \mathrm{rpm}$ for 48hrs. After the incubation, samples were taken for the analyses of bacteriocin. For more reliability, each run was conducted either in triplicate or duplicate and the results were represented as the arithmetic average [15].

\section{Optimization of culture conditions}

Several optimization experiments were performed in order to determine the medium and culture conditions that support the maximal production of bacteriocin. The experiments involved testing different media (nutrient broth [16], BHI [16], MLB broth [14], LB broth [17], MTY broth [18], R2 broth [19], Buffered Peptone water broth [19], trypticase Soy Broth [20], MRS broth [16] and Muller-Hinton broth [16]), inoculum size, temperature, $\mathrm{pH}$ and incubation period.

\section{Analytical methods \\ Determination of growth}

The growth of $B$. subtilis NK16 isolate was measured as the dry weight of cell material. A known volume of the culture was filtered with vacuum through predried and pre-weighed filter paper $(0.2 \mu \mathrm{m}$, Whatman). The filter paper was thereafter placed in an oven at $60^{\circ} \mathrm{C}$ for $24 \mathrm{hrs}$ and then weighted. The difference in weights represented the mass of cells in the samples of the culture. This method was used with pure culture of $B$. subtilis NK16 while in the elicited cultures this method was not followed because of the difficulty of 
separating two microorganisms which are growing in the same fermentative liquid.

\section{Determination of bacteriocin activity}

Bacteriocin activity was determined using the critical dilution assay which is similar to the minimum inhibitory concentration technique (MIC) for antibiotic assessment. This method involved preparation of a twofold dilution series of the $B$. subtilis NK16 culture to be tested and then bacteriocin activity was determined against $S$. aureus in each dilution using agar well diffusion assay.200 $\mu \mathrm{l}$ of an overnight growth culture of $S$. aureus containing approximately $1 \times 10^{7}$ cells $/ \mathrm{ml}$ was mixed with $25 \mathrm{~mL}$ of a sterile Muller Hinton agar kept at $45-50^{\circ} \mathrm{C}$ in a water bath. The mixtures were kept at the same temperature until poured into sterile plastic Petri dishes and allowed to solidify. Circular wells of $5 \mathrm{~mm}$ in diameter were cut using a sterile cork borer and then low melting temperature Muller Hinton agar was used to seal the bottom of the wells. $100 \mu \mathrm{l}$ aliquots of the filtered CFS were dispensed in the wells and then plates were incubated for $24 \mathrm{hrs}$ at $37^{\circ} \mathrm{C}$. Following the incubation, the growth inhibition zone around each well was examined. The highest dilution generating an inhibition zone indicated the strength of bacteriocin activity. Thus, the bacteriocin activity is a proportional to the reciprocal of the highest dilution factor producing a detectable inhibition zone (DF) [21]. The bacteriocin activity which is known as arbitrary unites (AU) was calculated using the following equation:

$$
\mathrm{AU} / \mathrm{ml}=\frac{1}{D F} \frac{1000}{\text { volums spotted in } \mu l}
$$

\section{Protein Estimation}

The protein concentration in the samples was estimated by the method of Bradford [22].

\section{Purification of bacteriocin \\ Precipitation with ammonium sulphate}

Bacteriocin was precipitated by ammonium sulphate at different saturation levels $(40,50,60,70,80) \%$. Ammonium sulphate was added to CSF slowly with gentle stirring at $4^{\circ} \mathrm{C}$. The precipitate was separated by centrifugation for $30 \mathrm{~min}$ at $10000 \mathrm{rpm}$. Then the precipitates were redissolved in an appropriate volume of phosphate buffer (0.1M, pH 7.2). Next, the dissolved precipitates were dialyzed separately, in phosphate buffer using dialysis membrane tubes $(1 \mathrm{kDa} \mathrm{MW}$ cutoff). Then, the dialysis bags contained precipitates were placed in 0.5 liter of phosphate buffer overnight at $4^{\circ} \mathrm{C}$. The buffer was replaced four times. The antibacterial activity of the dialyzed protein was determined by agar well diffusion assay using $S$. aureus as an indicator strain [23].

\section{Sephadex gel filteration}

The resulting bacteriocin was loaded on a column $(3 \times 20 \mathrm{~cm})$ of sephadex G150 gel filtration. Elution of proteins was performed with phosphate buffer (0.1 M, pH 7.2). The flow rate was adjusted to $36 \mathrm{ml} /$ hour and fractions of 3 $\mathrm{ml}$ were collected. Seventy six fractions were collected and the absorption of these fractions was measured at $280 \mathrm{~nm}$. The fractions were tested for antibacterial activity against $S$. aureus as an indicator strain by well agar diffusion assay. Fractions showed antimicrobial activity were mixed together in one tube and protein concentration with Bradford method and bacteriocin activity were determined [14].

\section{Characterization of bacteriocin \\ Susceptibility to proteases and thermal, pH stability}

The sensitivity of the bacteriocin produced from $B$. subtilis NK16 to proteolytic enzyme trypsin was tested. Trypsin was dissolved in $0.1 \mathrm{M}$ potassium phosphate buffer ( $\mathrm{pH}$ 7.2) in 
a test tube contained the bacteriocin solution with an activity of $80 \mathrm{AU} / \mathrm{ml}$ for a final concentration of $1 \mathrm{mg}$ trypsin/ ml. The control contained the bacteriocin solution with an activity of $80 \mathrm{AU} / \mathrm{ml}$ without trypsin. Tubes were incubated at $37{ }^{\circ} \mathrm{C}$ and bacteriocin activity was measured at zero time and after 30 and 90 mins using the well diffusion assay method [24, 25]. Furthermore, in order to test the thermo stability of bacteriocin, samples were exposed to different temperatures (30, $40,50,60,70,80,90)^{\circ} \mathrm{C}$ for 10 mins followed by cooling on an ice-bath. The residual activity was then determined by agar-well diffusion technique against indicator strain. In addition, bacteriocin preparation was treated with either $0.1 \mathrm{~N}$ $\mathrm{HCl}$ or $0.1 \mathrm{~N} \mathrm{NaOH}$ to achieve the desired $\mathrm{pH}$ values between 4 and 9. The $\mathrm{pH}$ adjusted crude extracts were incubated for 30 mins. After incubation, aliquots were neutralized and activity was measured by agar-well diffusion technique against indicator strain.

\section{Mode of bacteriocin action}

The mode of action of the bacteriocin against $S$. aureus was investigated. 0.5 $\mathrm{ml}$ of the partial purified bacteriocin with total activity of $640 \mathrm{AU} / \mathrm{ml}$ was added to10 $\mathrm{ml}$ of an overnight culture of S. aureus grown in nutrient broth at 37 ${ }^{\circ} \mathrm{C}$ (OD $600 \mathrm{~nm}=0.6$ of $S$. aureus). Control culture was prepared without adding bacteriocin. Changes in the turbidity at $600 \mathrm{~nm}$ and viable cells count $(\mathrm{cfu} / \mathrm{ml})$ were measured at zero time and after 10, 30, 60, and $120 \mathrm{~min}$ of incubation. Viable cells count was determined on nutrient agar plates [26].

Assessment of in vitro antibacterial activity of bacteriocin

The activity of bacteriocin at a concentration of $300,400,500,640$ AU/ml was tested against 29 clinical isolates of Staphylococcus spp including 21 isolates of $S$. aureus, 4 isolates of $S$. epidermidis and 4 isolates of $S$. saprophyticus. These isolates were collected from different hospitals in three cities (Baghdad, Al Kut and Baqubah) in Iraq. The inhibitory spectrum was determined using the agar well diffusion assay.

\section{Statistical analysis}

The results of antimicrobial activity of bacteriocin produced by Bacillus sp NK 16 against the clinical gram positive and negative isolates were statistically studied by using two-way variance analysis (ANOVA) for the separation of mean differences. A probability level of $P$ value $\leq 0.01$ was used in testing the statistical significance of the experimental data [27].

\section{Result and Discussion:}

Bacillus is an interesting genus to investigate the antimicrobial activity, since it produces a large number of peptide-antibiotics representing several basic chemical structures [28]. Although many species of Bacillus can synthesize antimicrobial peptides, the data on bacteriocins is limited to only few species of Bacillus [29]. In this study, 50 Bacillus sp. isolates were isolated from different soil samples collected from different parts in Baghdad. An identification process was followed to select the Bacillus sp. isolates based on morphological examination and biochemical characterizations according to Bergey's manual of systematic bacteriology which confirm that all isolates belong to the genus of Bacillus [30].

The 50 Bacillus isolates were subjected to screening process using $S$. aureus as an indicator strain in order to select the higher bacteriocin producing isolate that can be used for further experiments in this study. The screening was achieved in BHI broth and for more reliability all isolates were cultivated under the same conditions in terms of inoculum size, cells number, $\mathrm{pH}$, incubation period and shaking speed. Based on the results, culture supernatant of B. subtilis NK16 
isolate showed the maximum activity against $S$. aureus. Inhibition zone formed in well diffusion assay by bacteriocin produced by this isolate was $18 \mathrm{~mm}$ against $S$. aureus. Thereafter, $B$. subtilis NK16 isolate was chosen, and therefore was subjected to Analytical Profile Index (API 20E and API 50CH) Strep System. The results of API 20E and API 50CHB were compared and identified online using the identification software via online API database (bioMérieux, Inc) which revealed that $B$. subtilis NK16 isolate was Bacillus subtilis.

The next step was to investigate the optimized cultural parameters that are required for elevating bacteriocin production such as media, temperature, $\mathrm{pH}$ and inoculum size. In this study, different media were used in order to select the one that can support the maximum production of bacteriocin. It has been hypothesized that biosynthesis of peptides requires a rich medium [31], hence the effect of media composition on bacteriocin from B. subtilis NK16 production was tested. Based on the results presented in Figure (1A), the maximum production of bacteriocin was found in BHI with an activity of approximately $80 \mathrm{AU} / \mathrm{ml}$. Whereas, in the other media, production of bacteriocin was either low or completely suppressed.
In addition, bacteriocin production was determined after growing $B$. subtilis NK16 in BHI broth prepared with different initial $\mathrm{pH}$. As can be seen in Figure (1B), production of bacteriocin was obtained at $\mathrm{pH}$ ranging from 5 to 8 . Maximum bacteriocin production of 80 $\mathrm{AU} / \mathrm{ml}$ was observed in cultures with an initial $\mathrm{pH}$ of 6 and 7. In addition, no production was found in culture with an initial $\mathrm{pH}$ of 4 and 9.

In general, the cultivation temperature plays a crucial role in the microbial growth and synthesis of secondary metabolites. Therefore, it was necessary to investigate the optimum temperature that maximizes the production of bacteriocin. Figure (1C) shows that the maximum production of bacteriocin $(80$ $\mathrm{AU} / \mathrm{ml}$ ) was obtained at $30^{\circ} \mathrm{C}$. However, when the temperature of the incubation was less or more than $30^{\circ} \mathrm{C}$, bacteriocin production was consequently decreased. Inoculum size also represents an essential factor that usually affects the microbial growth rate and consequently the secondary metabolites production. Therefore, this factor was investigated using different inoculum sizes ranging from 1 to $5 \%$ (v/v). As shown in Figure (1D), the best inoculum size for the maximum bacteriocin production was $2 \%$ yielding an activity of approximately $80 \mathrm{AU} / \mathrm{ml}$ under the experimental conditions used in this work. 


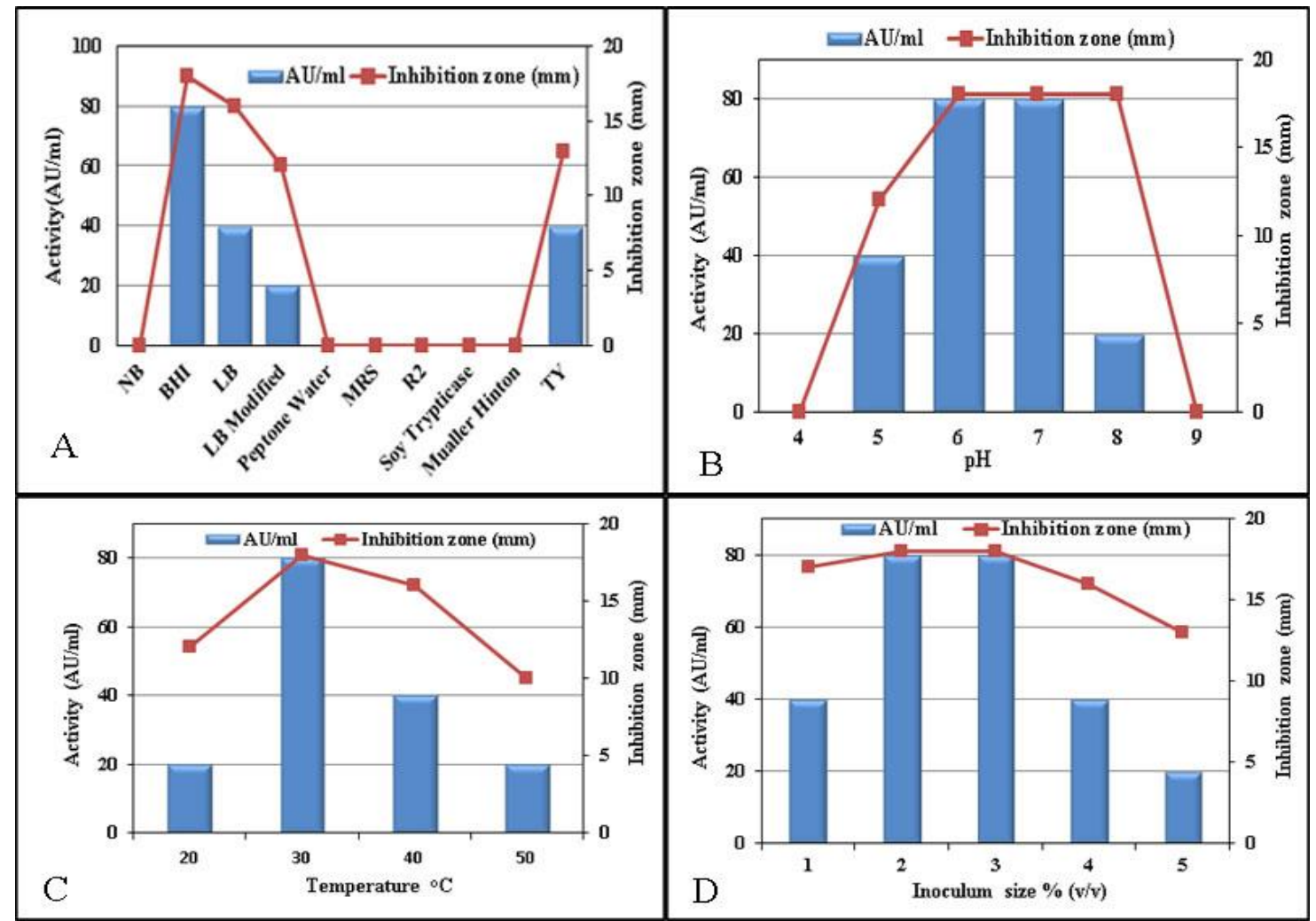

Fig. (1): Optimized cultural parameters for elevating bacteriocin production which were different media (A), different $\mathrm{pH}(\mathrm{B})$, different temperature $(\mathrm{C})$ and different inoculum size (D)

The growth of $B$. subtilis NK16 isolate in BHI broth was investigated. The typical time course of growth (dry weight) and bacteriocin production by B. subtilis NK16 is presented in Figure (2). The exponential phase started where biomass concentration noticeably increased from 0.16 to $2.96 \mathrm{mg} / \mathrm{ml}$ after $31 \mathrm{hrs}$ of incubation which marks the start of the stationary phase. Then, $B$. subtilis NK16 population was increased slightly to $3.3 \mathrm{mg} / \mathrm{ml}$ after $41 \mathrm{hrs}$ of cultivation. Thereafter, population growth was ceased, and the growth curve becomes horizontal. The production of bacteriocin was started during the exponential phase after $9 \mathrm{hrs}$ of incubation. At the end of the exponential phase (at $24 \mathrm{hrs}$ of incubation), the activity of bacteriocin was approximately $80 \mathrm{AU} / \mathrm{ml}$ which is maximum production obtained under the conditions used in this experiment. No further increasing was observed in the production of bacteriocin during the stationary phase suggesting that bacteriocin produced by $B$. subtilis NK16 is a primary metabolite and associated with growth. In this context, several studies have mentioned that numerous bacteriocins are produced during the active growth phase [32].

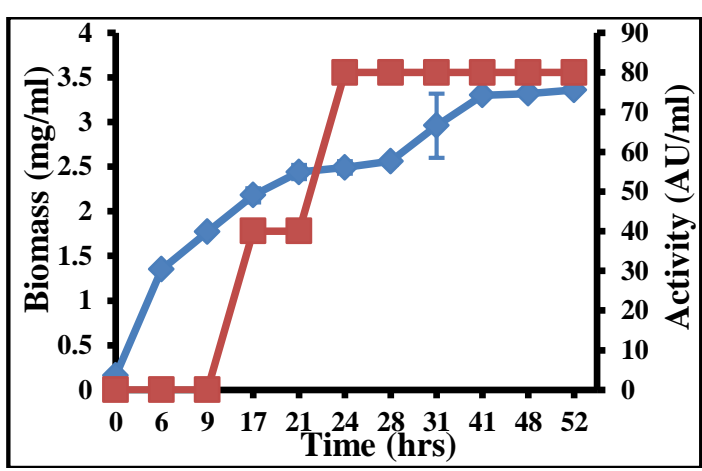

Fig. (2): Time course of cell growth $(\square)$ and bacteriocin production ( $\diamond)$ by B. subtilis NK16 in a shaker incubator at $30 \mathrm{C}^{\circ}$ and $150 \mathrm{rpm}$. 


\section{Purification of Bacteriocin}

Based on the results presented in Figures (3) and (4), maximum bacteriocin precipitation was obtained at $80 \%$ saturation level. The bacteriocin activity was $320 \mathrm{AU} / \mathrm{ml}$ with specific activity of 237.04 AU/mg. The precipitated bacteriocin was then loaded in sephadex G-150 column. As can be seen in Figure (5), three separated peaks were obtained in the separation profile.

The bacteriocin activity was detected in ten fractions corresponding to the second and third peak in fractions No. 56 to 65 . The active fractions were collected and the specific activity of the partial purified bacteriocin was increased to $853.33 \mathrm{AU} / \mathrm{mg}$ resulting in
38 fold purification with $24 \%$ yield (Table 1).

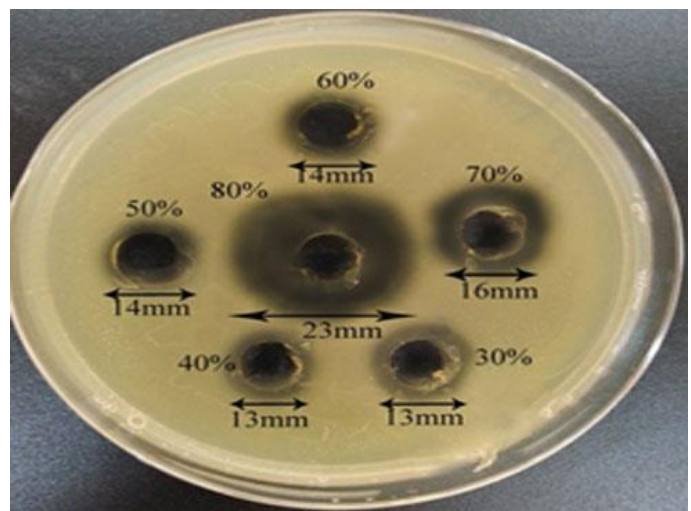

Fig.(3): Inhibition zone of partial purified bacteriocin of $B$. subtilis NK16 produced in a shaker incubator at $30 \mathrm{C}^{\circ}$ and $150 \mathrm{rpm}$ precipitated at different concentration of ammonium sulphate.

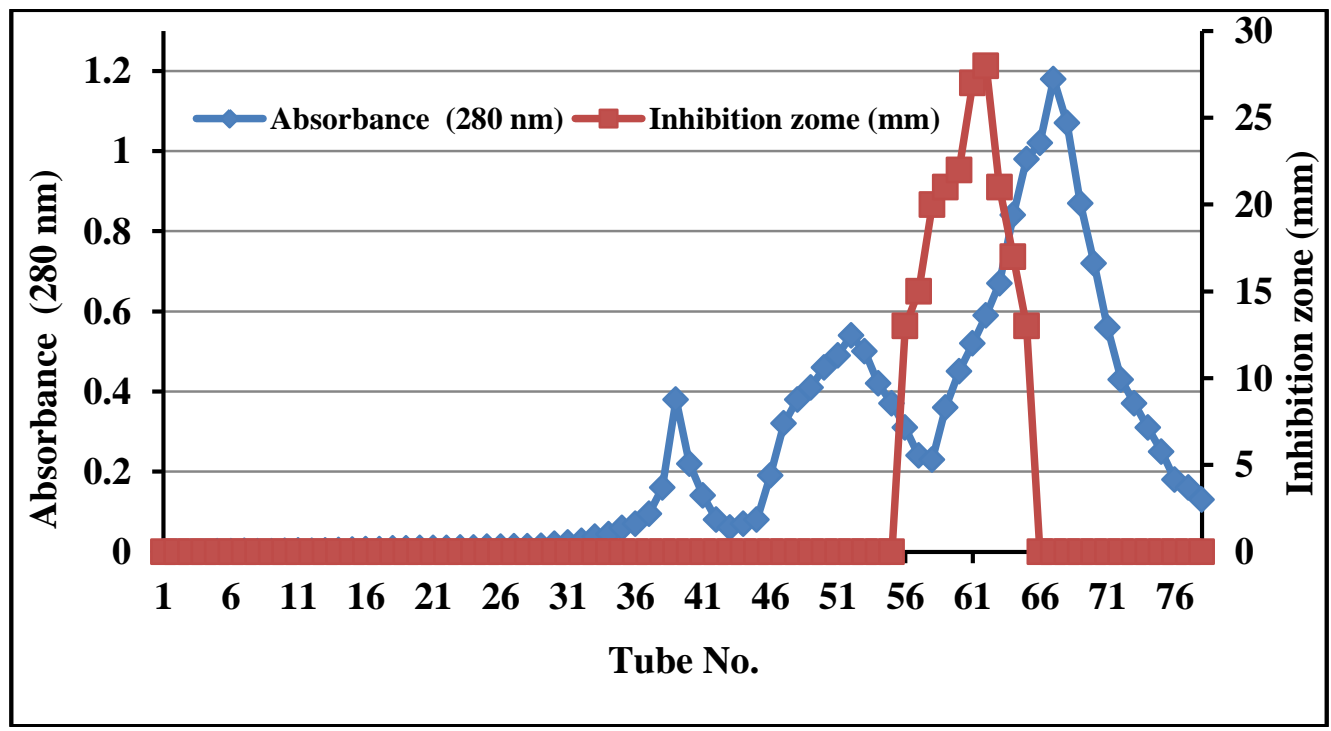

Fig. (4): Purification of bacteriocin by Sephadex G-150 column. Column was equilibrated and eluted with sodium phosphate buffer, $\mathrm{pH} 7$ at a flow rate of 0.6 $\mathrm{ml} / \mathrm{min}$.

Table (1): Summary of purification of bacteriocin from crude culture filtrate of B. subtilis NK16

\begin{tabular}{|c|c|c|c|c|c|c|c|}
\hline Step & $\begin{array}{c}\text { Volume } \\
(\mathrm{ml})\end{array}$ & $\begin{array}{c}\text { Total } \\
\text { activity } \\
(\mathrm{AU} / \mathrm{ml})\end{array}$ & $\begin{array}{c}\text { Protein } \\
\text { conec. } \\
\mathrm{mg} / \mathrm{ml}\end{array}$ & $\begin{array}{c}\text { Total } \\
\text { activity } \\
(\mathrm{Au})\end{array}$ & $\begin{array}{c}\text { specific } \\
\text { activity } \\
(\mathrm{AU} / \mathrm{mg})\end{array}$ & $\begin{array}{c}\text { Yield } \\
\%\end{array}$ & $\begin{array}{c}\text { Fold } \\
\text { purification }\end{array}$ \\
\hline Crude & 100 & 80 & 3.6 & 8000 & 22.2 & 100 & 1 \\
\hline $\begin{array}{c}\text { Precipitation with } \\
\text { Ammonium sulfate 80\% }\end{array}$ & 10 & 320 & 1.35 & 3200 & 237.04 & 40 & 11 \\
\hline $\begin{array}{c}\text { Gel filtration } \\
\text { Sephadex G-150 }\end{array}$ & 3 & 640 & 0.75 & 1920 & 853.33 & 24 & 38 \\
\hline
\end{tabular}




\section{Characterization of bacteriocin}

As can be seen in Figure (5), bacteriocin activity was reduced when treated with trypsin. The results showed that bacteriocin activity was decreased to $50 \%(40 \mathrm{AU} / \mathrm{ml})$ after $30 \mathrm{~min}$ of incubation and it was completely lost after 90 mins confirming the protein status of bacteriocin produced by $B$. subtilis NK 16 . Several studies demonstrated the sensitivity of bacteriocins to proteolytic enzymes such as Trypsin. In this context, Cherif [33, 34] reported the loss of bacteriocin activity produced by Bacillus thuringensis after treatment with proteolytic enzymes.

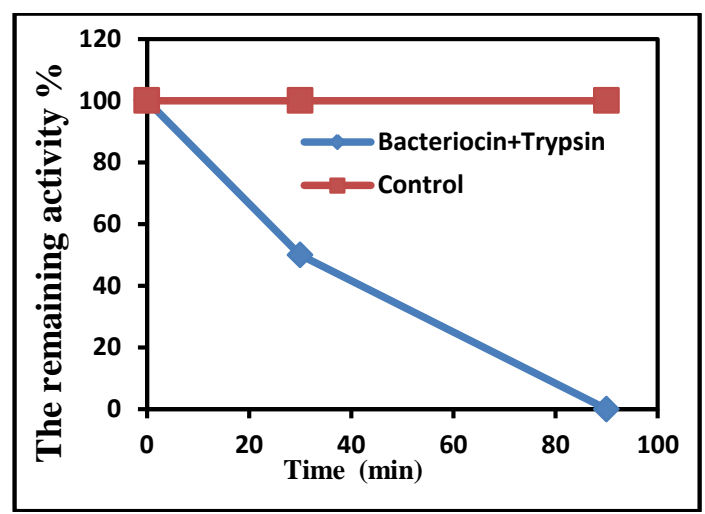

Fig.(5): enzyme sensitivity of bacteriocin from $B$. subtilis NK 16. Bacteriocin of $B$. subtilis NK 16 incubated with $1 \mathrm{mg} / \mathrm{ml}$ of trypsin for 30 and $90 \mathrm{~min}$. followed by bioassay for bacteriocin activity by agar-well diffusion assay.

Thermal stability of bacteriocin is an important criterion that can help to determine whether the bacteriocin belongs to the class of heat-labile or heat -stable protein [35]. As can be seen in Figure (6), the activity of bacteriocin remained stable after $10 \mathrm{~min}$ at 20,30, $40^{\circ} \mathrm{C}$ as no effect was observed on its activity. However, $50 \%$ of the bacteriocin activity was lost after exposure to $50^{\circ} \mathrm{C}$ for $10 \mathrm{~min}$. In addition, the activity of bacteriocin was obviously decreased to approximately $75 \%(20 \mathrm{AU} / \mathrm{ml})$ upon exposure to 60 ,
70 and $80^{\circ} \mathrm{C}$ for $10 \mathrm{~min}$. Bacteriocin activity disappeared at $90 \mathrm{C}^{\circ}$ for 10 mins. From the results, it can be concluded that the bacteriocin is heat -labile. In this context, Lee [36] reported that partially-purified bacteriocin from Bacillus polyfermenticus was inactivated by heating treatment at $70^{\circ} \mathrm{C}$ for $30 \mathrm{~min}$. Furthermore, Bizani and Brandelli [37] mentioned that the activity of bacteriocin produced from Bacillus cereus $8 \mathrm{~A}$ was lost when heated at $87^{\circ} \mathrm{C}$. Activity of the bacteriocin from $B$. subtilis NK16 was also tested for $\mathrm{pH}$ stability. As can be noticed in Figure (7), bacteriocin activity showed stability at $\mathrm{pH} 6$ and 7 in which the bacteriocin kept its stability of $80 \mathrm{AU} / \mathrm{ml}$ for 30 min. However, bacteriocin activity was decreased to approximately 50\% (40 $\mathrm{AU} / \mathrm{ml}$ ) at $\mathrm{pH} 5$ and 8 , whereas, no activity was observed at $\mathrm{pH} 4$ and 9 . The range of $\mathrm{pH}$ stability for bacteriocin activity differs from one to another. Some bacteriocins have a wide range activity of $\mathrm{pH}$ while others are active at a narrow range. In this context, purified bacteriocin from $B$. amyloliquifaciens showed an activity at $\mathrm{pH}$ ranging from 4 to 8,thuricin $\mathrm{S}$ produced by the $B$. thuringiensis was found stable at a variety of $\mathrm{pH}$ levels ranging from 3 to 10 and bacteriocin from Aeromonas hydrophila found stable at $\mathrm{pH}$ ranging from 3 to 8 [15, 38, 39].

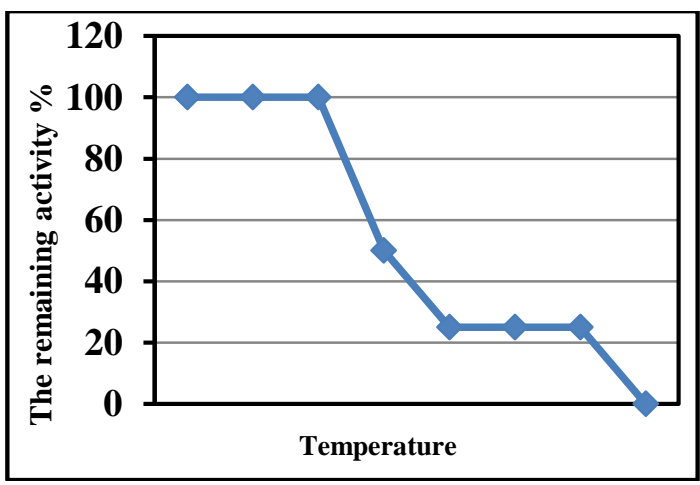

Fig.(6): The residual activity of bacteriocin produced by $B$. subtilis NK16 after exposed to different temperature for $10 \mathrm{~min}$. 


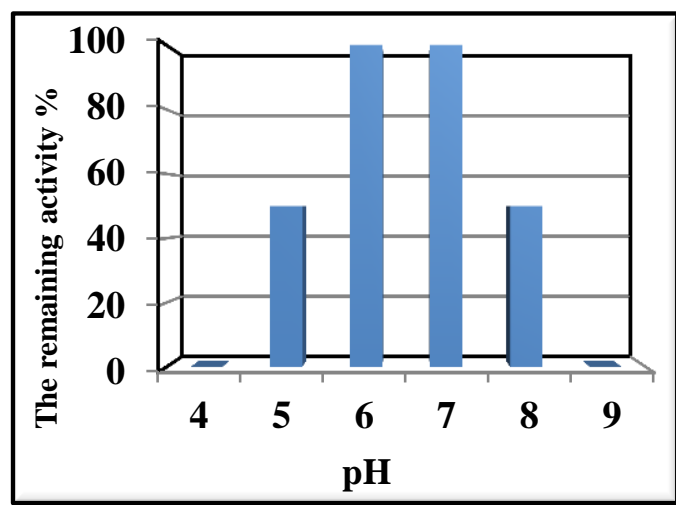

Fig.(7): pH stability of bacteriocin from $B$. subtilis NK16 after exposed to different $\mathrm{pH}$ for $30 \mathrm{~min}$.

\section{Mode of action of bacteriocin}

Most of bacteriocins produced from Bacillus species show a bactericidal effect with or without cell-lysis [40]. In the present study, the mode of action of the partially purified bacteriocin produced by $B$. subtilis NK16 was studied using $S$. aureus as an indicator strain. Figure (8) shows a rapid decline in the number of viable cells and optical density at $600 \mathrm{~nm}$ in the tube which contained $S$. aureus culture with bacteriocin. The number of cells in this tube was decreased to approximately zero within $2 \mathrm{hrs}$. Whereas, no effect was observed on the growth of S. aureus in the control tube. These results suggest that the bacteriocin has a bactericidal effect rather than bacteriostatic. Bactericidal mode of action leads to the death of a pathogen; therefore, it is able to eradicate the main population of undesirable microorganisms [41].

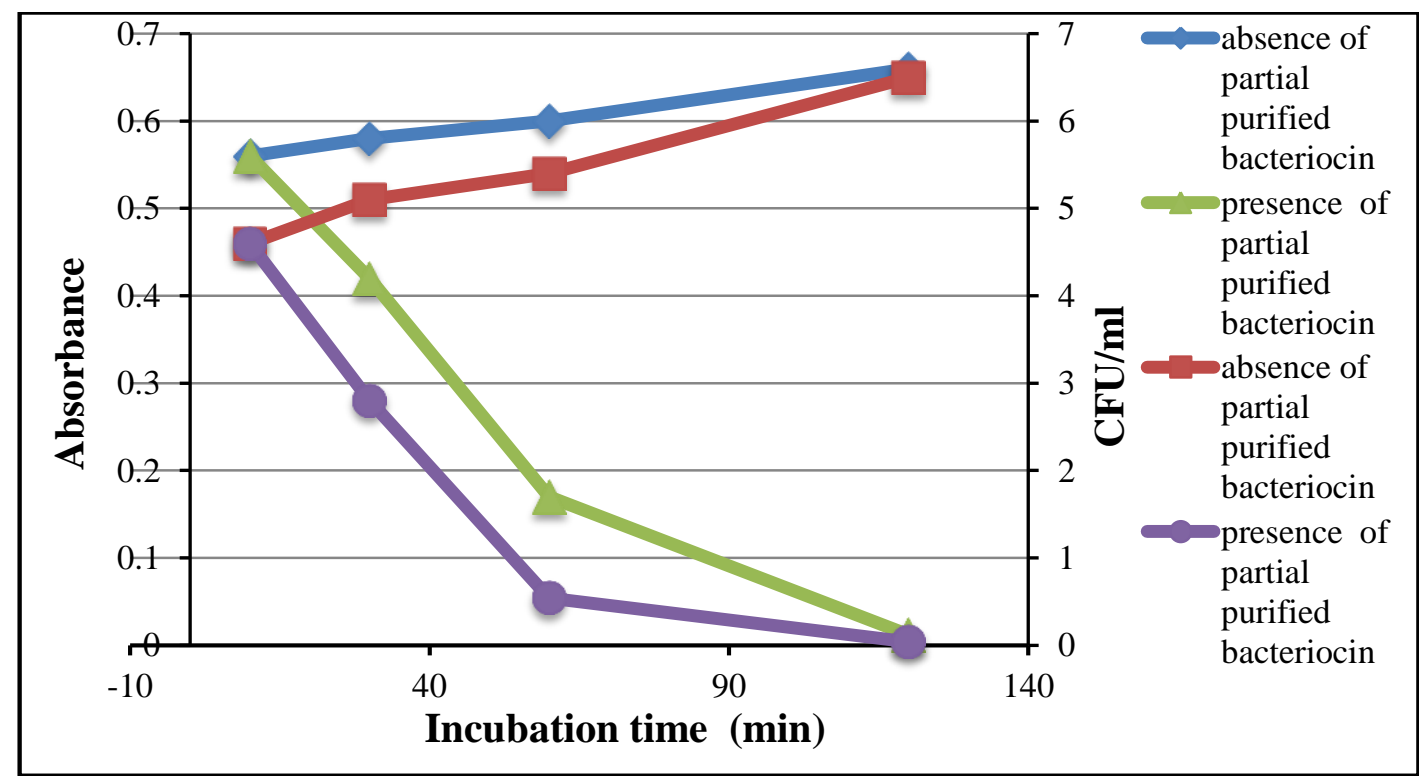

Fig.(8): Mode of action of partially purified bacteriocin produced by $B$. subtilis NK16 against $S$. aureus. Viable cell counts $(\mathrm{CFU} / \mathrm{ml})$ in the absence $(\square)$ or presence $(\bullet)$ of partial purified bacteriocin. Optical density at $600 \mathrm{~nm}$ in the absence $(\diamond)$ or presence $(\triangle)$ of partial purified bacteriocin.

Assessment of bacteriocin activity against Staphylococcus spp

The partial purified bacteriocin produced by $B$. subtilis $\mathrm{NK} 16$ was tested against several clinical isolates of Staphylococcus spp collected from different hospitals in Baghdad, Kut and Baqubah cities in Iraq. As can be noticed in Table (2), bacteriocin displays a significant activity against most $S$. aureus and $S$. epidermidis isolates, whereas it was less effective against $S$. saprophyticus isolates. Based on the results, bacteriocin was effective against $63 \%$ of clinical Staphylococcus spp isolates used in this study.

A statistical analysis was performed using Analysis of variance (ANOVA) 
models in order to measure the statistically significant differences of the effect of three different concentrations (640, 500 and $400 \mathrm{AU} / \mathrm{ml}$ ) of bacteriocin on clinical Staphylococcus spp isolates tested in this study. As shown in Table (3), the statistical analysis results of the sensitivity of different Gram positive bacterial isolates to three different bacteriocin concentrations $(640,500,400 \mathrm{AU} / \mathrm{ml})$ revealed no significant differences observed as the $\mathrm{P}$ values were 0.145 , 0.077 and 0.43 at bacteriocin concentrations 640, 500 and $400 \mathrm{AU} / \mathrm{ml}$ respectively when Probability at $\mathrm{P} \leq$ 0.01 .

Finally, certainly, these results have significance important as it contributes to the growing body of literature on finding an effective antibiotic against this microorganism. As mentioned earlier, S. aureus is considered as an important pathogenic bacterium which can cause several infections such as postoperative wound, minor skin infections and lower respiratory tract infections. However, there is a large volume of published studies describing the resistance of this bacterium to penicillin and its derivatives as well as many known antibiotics that are usually used to treat common $S$. aureus infections which is certainly considered as a serious problem in combating this pathogen [42, 43, 44].

Table (2): Activity of partial purified bacteriocin against several clinical isolates of Staphylococcus spp collected from different hospitals in Iraq.

\begin{tabular}{|c|c|c|c|c|c|c|}
\hline \multirow[b]{2}{*}{ No } & \multirow[b]{2}{*}{ Isolates } & \multirow{2}{*}{$\begin{array}{c}\text { Clinical isolates } \\
\text { source }\end{array}$} & \multicolumn{4}{|c|}{ Inhibition zone (mm) } \\
\hline & & & $\begin{array}{c}300 \\
\mathrm{AU} / \mathrm{ml}\end{array}$ & $\begin{array}{c}400 \\
\mathrm{AU} / \mathrm{ml}\end{array}$ & $\begin{array}{c}500 \\
\mathrm{AU} / \mathrm{ml}\end{array}$ & $\begin{array}{c}640 \\
\mathrm{AU} / \mathrm{ml}\end{array}$ \\
\hline 1 & S. aureusA1 & Al-Imam Ali hospital (Baghdad) & - & 13 & 26 & 30 \\
\hline 2 & S. aureus A2 & Al-Imam Ali hospital (Baghdad) & - & - & - & - \\
\hline 3 & S. aureusA3 & Al-Imam Ali hospital (Baghdad) & - & - & - & 15 \\
\hline 4 & S.aureusA6 & Al-Imam Ali hospital (Baghdad) & - & 13 & 18 & 26 \\
\hline 5 & S. aureus A15 & Al-Imam Ali hospital (Baghdad) & - & - & - & - \\
\hline 6 & S. aureus A24 & Al-Imam Ali hospital (Baghdad) & - & - & - & - \\
\hline 7 & S. aureus A26 & Al-Imam Ali hospital (Baghdad) & - & - & - & 17 \\
\hline 8 & S. aureus B7 & Al ShaheedAlsader hospital (Baghdad) & - & 16 & 24 & 32 \\
\hline 9 & S. aureus B10 & Al ShaheedAlsader hospital (Baghdad) & - & 13 & 20 & 33 \\
\hline 10 & S. aureusB7 & Al ShaheedAlsader hospital (Baghdad) & - & 16 & 24 & 32 \\
\hline 11 & S. aureusB11 & Al ShaheedAlsader hospital (Baghdad) & - & - & - & - \\
\hline 12 & S. aureusB13 & Al ShaheedAlsader hospital (Baghdad) & - & - & - & - \\
\hline 13 & S. aureusB14 & Al ShaheedAlsader hospital (Baghdad) & - & - & 16 & 21 \\
\hline 14 & S. aureus B10 & Al ShaheedAlsader hospital (Baghdad) & - & 13 & 20 & 33 \\
\hline 15 & S. aureusC1 & Baqubah hospital (Baqubah city) & - & - & - & 13 \\
\hline 16 & S. aureusC2 & Baqubah hospital (Baqubah city) & - & - & - & - \\
\hline 17 & S. aureusC3 & Baqubah hospital (Baqubah city) & - & - & - & - \\
\hline 18 & S. aureusC8 & Baqubah hospital (Baqubah city) & - & - & - & 19 \\
\hline 19 & S. aureusC14 & Baqubah hospital (Baqubah city) & - & - & - & - \\
\hline 20 & S. aureusD6 & Al-kut hospital (Al kut city) & - & - & 14 & 21 \\
\hline 21 & S. aureus D10 & Al-kut hospital (Al kut city) & - & 15 & 22 & 34 \\
\hline 22 & S. epidermidis B1 & Al ShaheedAlsader hospital (Baghdad) & - & 11 & 19 & 28 \\
\hline 23 & S. epidermidis B9 & Al ShaheedAlsader hospital (Baghdad) & - & - & 13 & 19 \\
\hline 24 & S. epidermidis B12 & Al ShaheedAlsader hospital (Baghdad) & - & 13 & 26 & 35 \\
\hline 25 & S. epidermidis B15 & Al ShaheedAlsader hospital (Baghdad) & - & - & 13 & 19 \\
\hline 26 & S.saprophyticus C5 & Baqubah hospital (Baqubah city) & - & - & - & - \\
\hline 27 & S. saprophyticus $\mathrm{ClO}$ & Baqubah hospital (Baqubah city) & - & - & - & - \\
\hline 28 & S. saprophyticus C11 & Baqubah hospital (Baqubah city) & - & - & - & 12 \\
\hline 29 & S. saprophyticus $C 12$ & Baqubah hospital (Baqubah city) & - & - & - & - \\
\hline
\end{tabular}


Table (3): Statistical analysis for bacteriocin effect produced by B. subtilis NK 16 in three concentrations against several clinical isolates of Staphylococcus spp collected from different hospitals in Iraq.

\begin{tabular}{|c|c|c|c|c|c|c|}
\hline Isolate & No & mean & SD & $\mathrm{F}$ value & $\mathrm{P}$ value & comment \\
\hline \multicolumn{7}{|l|}{$640 \mathrm{AU} / \mathrm{ml}$} \\
\hline S. aureus & 21 & 15.52 & 13.82 & \multirow[b]{3}{*}{1.86} & \multirow[b]{3}{*}{0.145} & \multirow{3}{*}{ No significant } \\
\hline S. epidermidis & 4 & 25.25 & 7.76 & & & \\
\hline S. saprophyticus & 4 & 3 & 6 & & & \\
\hline \multicolumn{7}{|l|}{$500 \mathrm{AU} / \mathrm{ml}$} \\
\hline S. aureus & 21 & 8.76 & 10.66 & \multirow[b]{3}{*}{2.36} & \multirow[b]{3}{*}{0.077} & \multirow{3}{*}{ No significant } \\
\hline S. epidermidis & 4 & 17.75 & 6.18 & & & \\
\hline S. saprophyticus & 4 & 0 & 0 & & & \\
\hline \multicolumn{7}{|l|}{$400 \mathrm{AU} / \mathrm{ml}$} \\
\hline S. aureus & 21 & 4.71 & 6.87 & \multirow[b]{3}{*}{0.97} & \multirow{3}{*}{0.43} & \multirow{3}{*}{ No significant } \\
\hline S. epidermidis & 4 & 6 & 6.97 & & & \\
\hline S. saprophyticus & 4 & 0 & 0 & & & \\
\hline
\end{tabular}

Probability at $\mathrm{P} \leq 0.01$

\section{Conclusion:}

The current situation, where antibiotic resistance is becoming increasingly common, has created a therapeutic challenge to the medical community where the development of new approaches and alternative treatments for such infections is becoming increasingly essential. Bacteriocin could be the suitable alternative antimicrobial for several pathogens particularly against those which showed resistance to most usefulness antibiotics such as Staphylococcus spp. In general, bacteriocins are a narrow spectrum antimicrobial agent. However, many researchers believe that the narrow spectrum antimicrobial activity of bacteriocins could be a positive point. One of the limitations of using broad spectrum antibiotics is that they kill almost any bacterial species which is specifically not resistant to the drug. Therefore, broad spectrum antibiotics may develop resistance in both pathogen and commensal bacteria. In fact, Bacteriocins provide an alternative solution with their relatively narrow spectrum of activity, they can be considered as a designed drug which targets the specific pathogen. Thus, in the future, bacteriocins can be used as an alternative and novel therapeutic agent against pathogens.

\section{Acknowledgment}

The authors would like to acknowledge the financial support from The Ministry of Higher Education and Scientific Research of Iraq.

\section{References:}

[1]Wainwright, M. 1990. Miracle Cure: The Story of Antibiotics. Cambridge, Blackwell.

[2]Boyce, J. M.; Cookson, B.; Christiansen, K.; Hori, S.; VuopioVarkila, J.; Kocagöz, S.; Öztop, A. Y.; Vandenbroucke-Grauls, C. M. J. E.; Harbarth, S. and Pittet, D. 2005. Meticillin-resistant S. aureus. The Lan. Infect. Disea.5 (10): 653-663.

[3]Croft, A.; D'antoni, A. and Terzulli, S. 2007. Update on the antibacterial resistance crisis. Medic. Sci. Mon.13: 103-118.

[4]Deurenberg, R. H. and Stobberingh, E. E. 2008. The evolution of $\mathrm{S}$. aureus. Infection, Gen. and Evo.8: 747-763.

[5]Kareem, S. M.; Al-Jubori, S. S. and Ali, M. 2015. Prevalence of erm Genes among Methicillin Resistant S. aureus MRSA Iraqi Isolates. Int. J. Curr. Microbiol. App. Sci, 4(5), 575585

[6]Al-Dahbi, A. M. and Al-Mathkhury, H. J. 2013. Distribution of Methicillin Resistant S. aureus in Iraqi patients and Healthcare Workers. Iraqi J. Sci, 54(2), 293-300. 
[7]Mulvey, M. and Simor, A. 2009. Antimicrobial resistance in hospitals: How concerned should we be?.C. Medic. Associ. J.180: 408-415.

[8]Cleveland, J.; Montville, T.J.; Nes, I.F. and Chikindas, M.L. 2001. Bacteriocins: safe, natural antimicrobials for food preservation. Int. J. Food Microbiol, 71, 1-20.

[9]Cotter, P. D. and Hill, C.; Ross, R. P. 2005. Bacteriocins: developing innate immunity for food. Nat. R. Microbiol., 3(10): 777-788.

[10] Snyder, A. B. and Worobo, R. W. 2014. Chemical and genetic characterization of bacteriocins: antimicrobial peptides for food safety. J. of the Sci. of Food and Agri., 94(1): 28-44.

[11] Hammami, R.; Fernandez, B.; Lacroix, C. and Fliss, I. 2013. Antiinfective properties of bacteriocins: an update. Cellular and Molecular Life Sci., 70(16), 2947-2967.

[12] Nicholson, W. L. 2002. Roles of Bacillus endospores in the environment. Cellular and Molecular Life Sci CMLS, 59(3):410-416.

[13] Cappuccino, J. G. and Sherman, N. 2002. Microbiology: a laboratory manual Vol.7. Pearson/Benjamin Cummings.

[14] Hammami, I.; Jaouadi, B.; Ben Bacha, A.; Rebai, A.; Bejar, S.; Nesme, X. and Ali, R. 2012. Bacillus subtilis Bacteriocin Bac 14B with a Broad Inhibitory Spectrum: Purification, Amino Acid Sequence Analysis, and Physicochemical Characterization. Biotechnol. andBio,Eng, 17: 41-49.

[15] Lisboa, M. P.; Bonatto, D.; Bizani, D.; Henriques, J. A. and Brandelli, A. 2010. Characterization of a bacteriocin-like substance produced by Bacillus amyloliquefaciens isolated from the Brazilian Atlantic forest. Inter. Microbiol., 9(2): 111-118.
[16] Bizani, D. and Brandelli, A. 2004. Influence of media and temperature on bacteriocin production by Bacillus cereus $8 \mathrm{~A}$ during batch cultivation. Appl. Microbiol. Biotechnol, 65: 158-162.

[17] Naz, S. A. and Rasool, S. A. 2013. Isolation, production and characterization of bacteriocins produced by strains from indigenous environments. Pak. J. of Botan., Karachi, 45(1): 261-267.

[18] Ansari, A.; Aman, A.; Siddiqui, N. N.; Iqbal, S. and Qader, S. A. 2012. Bacteriocin (BAC-IB17): screening, isolation and production from Bacillus subtilis KIBGE IB-17. Pak. J. Pharm. Sci, 25(1): 195-201.

[19] Tabbene, O.; Slimene, I. B.; Djebali, K.; Mangoni, M. L.; Urdaci, M. C. and Limam, F. 2009. Optimization of medium composition for the production of antimicrobial activity by Bacillus subtilis B38. BiotechnolProg., 25(5):1267-1274.

[20] Motta, A. S. and Brandelli, A. 2008. Evaluation of environmental conditions for production of bacteriocin-like substance by Bacillus sp. strain P34. W. J. of Microbiol and Biotechnol, 24(5): 641-646.

[21] Mayr-Harting, A.; Hedges, A.J. and Berkeley, C.W. 1972. Methods for studying bacteriocins. Methods Microbiol7, 315-412

[22] Kruger, N.J. 2002. The Bradford method of protein quantification, $\mathrm{pp}$ 15-21. In J.W. Walker (ed.). The Protein Protocols Handbook, 2nd ed. Humana Press Inc.; Totowa, New Jercy.

[23] Charles, P.; Devanathan, V.; Anbu, P.; Ponnuswamy, M. N.; Kalaichelvan, P. T.; and Hur, B. K. (2008). Purification, characterization and crystallization of an extracellular alkaline protease from Aspergillusnidulans HA- 10. J. of bas. Microbial., 48(5): 347-352. 
[24] Chin, H. S.; Shim, J. S.; Kim, J. M.; Yang, R. and Yoon, S. S. 2001. Detection and antibacterial activity of a bacteriocin produced by Lactobacillus plantarum. Food Sci. and Biotechnol., 10(5): 461-467.

[25] Yamato, M., Ozaki, K. and Ota, F. 2003. Partial purification and characterization of the bacteriocin produced by Lactobacillus acidophilus YIT 0154. Microbiol. Resea.,158 (2):169-172.

[26] Sirtori, L. R.; Motta, A. D. S. D.; and Brandelli, A. 2008. Mode of action of antimicrobial peptide $\mathrm{P} 45$ on Listeria monocytogenes. Journal of basic microbiology, 48(5):393400.

[27] Myers, R. H.; and Montgomery, D. C. 2002. Response Surface Methodology: Process and Product Improvement with Designed Experiments.Von Dohren, H. 1995. Peptides. Biotechnol., 28,129-71.

[28] Stein, T. 2005. Bacillus subtilis antibiotics: structures, syntheses and specific functions. Molecular Microbiol., 56(4): 845-857.

[29] Claus, D. and Berkeley, R.C.W. 1986. Genus Bacillus Chon 1872. In: Sneath P.H.A (Eds), Bergey's manual of Systematic Bacteriology, Vol. 2. Williams and Wilkins Co.; Baltimore, MD. Pp 1105-1139.

[30] Lisboa, M. P.; Bonatto, D.; Bizani, D.; Henriques, J. A. and Brandelli, A. 2010. Characterization of a bacteriocin-like substance produced by Bacillus amyloliquefaciens isolated from the Brazilian Atlantic forest. Inter. Microbiol., 9(2):111-118.

[31] Baker, R.C.; Winkowski, K.and Montville, T. G. 1996. pHcontrolledfermentors to increase production of leuconocin $\mathrm{S}$ by Leuconostocparamesenteroides. Proc. Biochem., 31: 225-228.

[32] De Vuyst, L.; Callewaert, R. and Crabbe K.. 1996. Primary metabolite kinetics of bacteriocin biosynthesis by Lactobacillus amylovorusand evidence for stimulation of bacteriocin under unfavorable growth conditions. Microbiol.142:817-827.

[33] Cherif, A.; Ouzari, H.; Daffonchio, D.; Cherif, H.; Ben Slama, K.; Hassen, A.; Jaoua, S. and Boudabous, A. 2001. Thuricin 7: a novel bacteriocin produced by Bacillus thuringiensis BMG1. 7, a new strain isolated from soil. Lett. in Appl. Microbiol., 32(4):243-247.

[34] Cherif, A.; Rezgui, W.; Raddadi, N.; Daffonchio, D. and Boudabous, A. 2008. Characterization and partial purification of entomocin 110, a newly identified bacteriocin from Bacillus thuringiensis subsp. Entomocidus HD110. Microbiol. Resea., 163(6): 684-692.

[35] Heng, N.C.K, Wescombe, P.A.; Burton, J.P.; Jack, R.W. and Tagg, J. R. 2007. The diversity of bacteriocins in Gram-positive bacteria. In: Bacteriocins: Ecol. and Evol. Riley MA and Chavan M. Springer, Berlin.pp. 45-92.

[36] Lee, K. H.; Jun, K. D.; Kim, W. S. and Paik, H. D. 2001. Partial characterization of polyfermenticin SCD, a newly identified bacteriocin of Bacillus polyfermenticus .Lett. inAppl. Microbiol, 32:146-151.

[37] Bizani, D. and Brandelli, A. 2002. Characterization of a bacteriocin produced by a newly isolated Bacillus sp. Strain 8 A. J. of Appl.. 93(3):512-519.

[38] Motta, A.S.; Loreuzeni, D.M. and Brandelli, A. 2007. Purification and partial characterization of an antibacterial peptide produced by a novel Bacillus sp. isolated from the Amazon basin. Curr. Microbiol, 54, 282-286.

[39] Ali, M. R.; Majeed, A. H. and Shakir, S. M.2011.Influence of chemical and physical conditions on the production of bacteriocin by 
Aeromonashydrophila. Baghdad Science Journal, 9(2).

[40] Aunpad, R. and Na-Bangchang, K. 2007. Pumilicin 4, a novel bacteriocin with anti-MRSA and antiVRE activity produced by newly isolated bacteria Bacillus pumilus strain WAPB4. Current Microbiol., 55(4): 308-313.

[41] Sharma, N.; Kapoor, R.; Gautam, N. and Kumari, R. 2011. Purification and Characterization of Bacteriocin Produced by Bacillus subtilis R75 Isolated from Fermented Chunks of Mung Bean
(Phaseolusradiatus). Food Technol. Biotechnol., 49(2): 169-176.

[42] Lyon, B. and Skurray, R. 1987. Antimicrobial resistance of S. aureus: genetic basis. Microbiol. andMolecul. Bio. Re. 51: 88-134.

[43] Croft, A.; D'antoni, A. and Terzulli, S. 2007. Update on the antibacterial resistance crisis. Medic. Sci. Mon., 13: 103-118.

[44] Deurenberg, R. H. and Stobberingh, E. E. 2008. The evolution of $S$. aureus. Infection, Gene. andEvo., 8(6): 747-763.

\section{كشف و تنقية وتوصيف البكتريوسن المنتج من عزلة

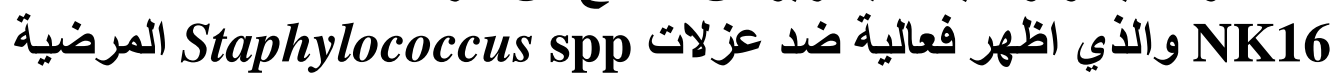

خالا جابر كاظم

فؤاد نجم عبد

قسم التقانات الاحيائية، كلية العلوم، جامعة بغداد ، بغداد ، العراق

البريد الاكتروني:Khalidjaber@scbaghdad.edu.iq

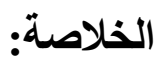

يعد البكتريوسن مضاد بكتيري ببتيدي مهم يستخدم في العديد من المجالات الصناعية و الطبية بسبب خو اصنة

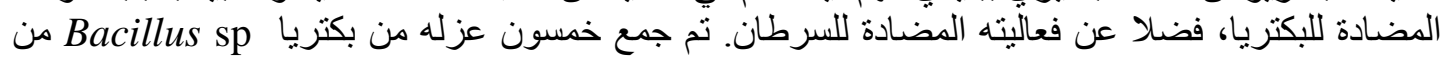

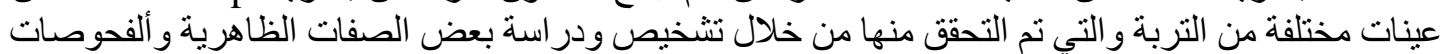

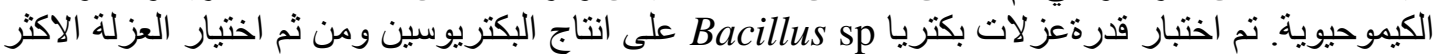

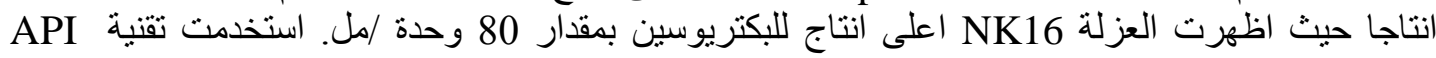

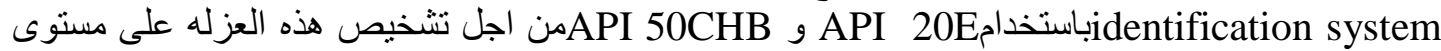

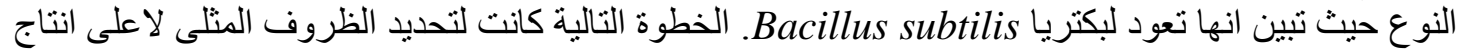

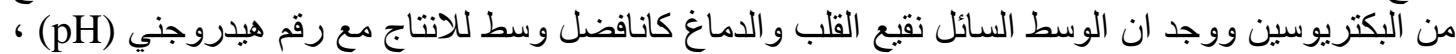

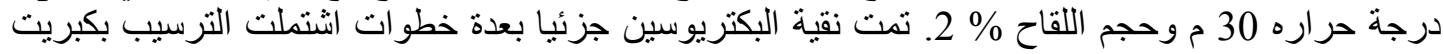

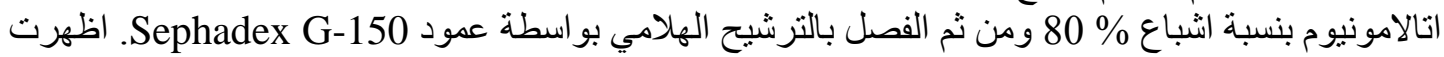

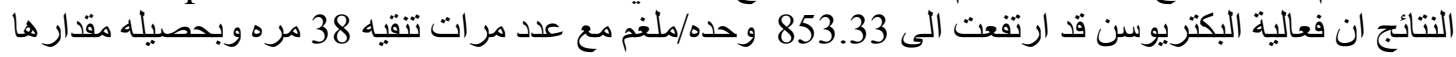

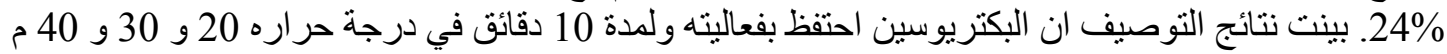

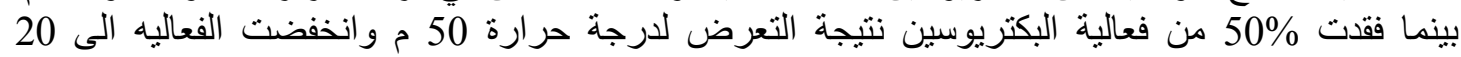

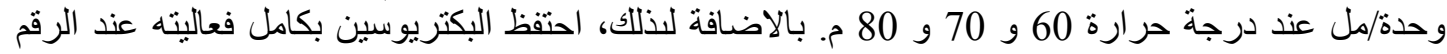

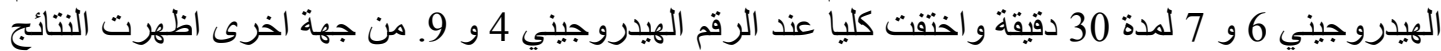

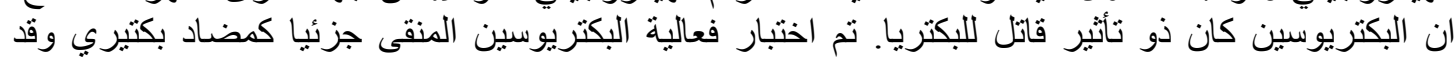

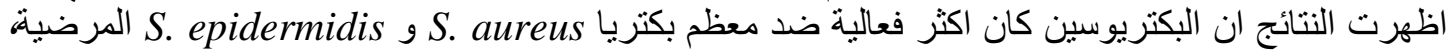

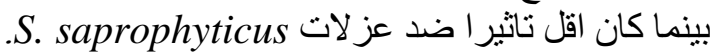

الكلمات المفتاحيه: باسيليس سيتلس : البكتريو سين: تنقيه: توصيف: الفعاليه الضد مايكروبيه: ستافلوكوكس . 